\title{
Renaissance and Development of Translation in the Arab World
}

\author{
Dr. Khalid Rokan Mansoor
}

Al-Turath University, Baghdad, Iraq

\begin{abstract}
Received: 01 Jun 2021; Received in revised form: 01 Jul 2021; Accepted: 08 Jul 2021
(C)2021 The Author(s). Published by TheShillonga. This is an open access article under the CC BY license (https://creativecommons.org/licenses/by/4.0/)
\end{abstract}

\begin{abstract}
The primary purpose of this paper is to discuss the history of translation in the Arab world and the methods were used at that time by Arab translators. The discussion presented in this paper also shows the importance of translation in the Arab world and its role in many fields of life such as science, economy, culture and religion. The paper also sheds light on the important changes that occurred in the Arab translations along the centuries. The literary translation and the vital role of translators are to be taken under consideration.
\end{abstract}

Keywords - Arab translation, Bait Al-Hikma, history of translation and literary translation.

\section{INTRODUCTION}

Over the centuries, people have been introduced to each other and communicated by the most dynamic and complicated means, which is language. Each nation uses and speaks its language and represents its culture. Some nations have the same cultural customs but speak a different language or vice versa, and communication becomes very difficult. According to Fasold and Linton (2006), language is "a finite system of elements and principles that make it possible for speakers to construct sentences to do particular communicative jobs" (p.9). This dictum hypothesises something true also for the linguistic phenomenon of the translation process. Thus, the main aim of language is to obtain a communicative function.

Hatim and Munday (2004, p.3) pointed out that translation can only be discussed from two various concepts: the "process", which designates the performance of rendering an ST from a particular language into a TT in another language, and the "product", which refers to the translated text. Shuttleworth and Cowie (1997, p.181) proved that translation is a comprehensive concept that paves the way to its being sorted out through different methods.

In the same fashion, Aziz and Lataiwish (2000, p.4) indicated that translation as a "process" pertains to human beings' interest and behaviour, which people have used and then have made evident sense thereof. As a "product", it is primarily the outcome of human beings' activity and interest in the form of translated texts. The same distinction is made by Dejica (2010), who had also put forward a functional-structural translation method consisting of a three-stage, nine-step translation process (p.129).

\section{THE HISTORY OF ARAB TRANSLATION}

The history of translation in the Arab world, according to Baker (1992, p.318), is known to have sparked the first established large-scale translation interests in history. These interests and activities had started during the era of the Umayads (661-750) and reached their climax under the Abbasids (750-1258), especially during the rule of AlMaamun (813-33). Thus, it is known as the Golden Era of translation. The Arabs had used translation or at least practised convenient translations before the advent of Islam. Before Islam, they were linked with other nations and cultures by travelling and exchanging trade.

Nevertheless, the substantial translation achievements of Arab scholars emerged during the Abbasid era $8^{\text {th }}-13^{\text {th }}$ centuries. As a result of the prevalence and dominance of a mighty Islamic empire, the Arab nations were in frequent contact with other sophisticated civilisations such as the Spanish, Indians, Persians, and the Byzantines (Redouane, 1980). During Abu Jaafar Al-Mansour rule in the $8^{\text {th }}$ century, the translation field was granted much attention by the Caliphate, and the first books that had been 
translated are scientific. This step motivated the successor ruler to continue the good auspices of translation(Mansoor, 2020).

Thus, Al-Maamoun established in 820-832, Bait Al-Hikma (The House of Wisdom) in Baghdad, which functioned as an academy library and translation group which included sixty-five translators. Therefore, he collected all the philosophers, scientists and scholars in Bait Al-Hikma, and they translated scientific and philosophical works from Greek. Most translators in Bait Al-Hikma were using the Syriac language as an intermediary language between Arabic and Greek.

In sum, the Translation in the history of the Arab world plays a crucial role, distinguishing merit that irradiates its primary role among the most remarkable civilisations until nowadays. Nevertheless, of course, translation needs to be related to other ingredients of what makes a civilisation. Thus, while the spiritual and cultural references of the glorious Quran and poetry were a dispersed force conveying its property, translation has given the Arab world an equiponderant through the centripetal force that attracted a diversity of knowledge patterns and, of course, enhanced for its transitivity and exchangeability(Mansoor, 2017).

\section{THE METHODS OF ARAB TRANSLATION IN BAIT AL-HIKMA}

According to several historical records, The Abbasid era translators in Bait Al-Hikma were working in groups. Their techniques and procedures depended on the distribution of duties taking into consideration the qualification of each translator. They used many methods to achieve their work, such as surveys and analyses of the original text and then translated it. The second important method is the involvement of an editor meant to hone the text into the style of the TL text. Finally, the amendment and revision of the translated version were done by the same translator as the one who translated it (Redouane, 1980). The duties of the Abbasid translators consisted not only in presenting works of scientific importance but also included a survey on "terminology" and phraseology and collated specialised glossaries. This task was marginal yet substantial, and the translation of Greek scientific works represented the exact given orders for them.

Assamara (1982, p.216) states that the Abbasid translators in Dar Al Hikma dealt with terminology by adopting two main methods: "word-for-word" translation and the use of derivation and etymology, which generally were based on the form of semantic extensions. Notwithstanding, when they could not find the adequate equivalence of terms or expressions, they usually used the Greek terms and made the future translators of Arabic predict the suitable equivalence (Salah,1979, p.47). During the Abbasid dynasty, Baghdad became a central place of the cultures of that time, not only in the Arab nations but also worldwide. As a result, all branches of science were translated, and thus one set up the primary methods of translations. Two main methods of translation were established at that time: "literal" and "free" translation (Mansoor, 2018).

\section{THE MOST IMPORTANT TRANSLATORS AT THE ARAB HISTORY}

Among the pioneers in translation, Yuhanna Ibn Al Batriq and Abd Al Masih Ibn Naaman Al Himsi were wellknown among the scholars who practised literal translation. Since their method aims to find each given language the equivalent items in the Arabic language, it also aims to maintain the same structural aspect of the original text in the target language (Remke, 1976, p.16). Unfortunately, many SL words and expressions did not have suitable equivalents in Arabic, so they used loan words widely, making the translated versions sometimes look impenetrable.

The second type is "free translation", which was first used by Hunain Ibn Ishaq and his group of translators. It is different from literal translation. It concentrated on conveying the meaning of the given language into Arabic; the translator had to pay more attention to the content, the idea and the meaning of the sentence rather than on the SL words or structure. According to this type of translation, the translator had to investigate and analyse the SL text and, therefore, find out its meaning and restructure it according to the Arabic structure, whether the respective syntactic structures matched up or not. So, the second type concentrates on the semantic rather than the syntactic aspect.

In the same way, Salahaddein Al Safadi, in the fourteenth century, established a third type. This type, he believed, was the most appropriate, especially for other works than scientific books. This type was mentioned throughout the history of translation (Khulilsi, 1982, p.216). Moreover, Al-Biruni (985-1066) was considered the leading personality in the history of Arabic translation. He translated many literary works into the Arabic language, especially from Greek, Indian and Persian. He was described as the master of Arabic translation at that time and all his works as masterpieces. During his teenage, AlBiruni had acquired considerable knowledge of science, and by the end of the tenth century, he had studied the latitude of Kath city. Later, he had written many books in many various fields, Al-Darwish (1977, p.23). Kharma (1983, p.222) states that "only a very small fraction of the 
very rich Arab heritage has been translated into modern languages, and it is one of our basic duties to start doing that on a systematic basis".

\section{THE ROLE OF THE TRANSLATOR}

When translation seems to be an exceedingly tricky process involving different constituents, the translator has to be well aware of all the constituents, which would eventually affect translation quality, characteristics and readings. Then, the translator assumes the mission of communicating the specific meaning of an extension of the source language to the target language. After that, the translator plays a crucial role in placing himself as the nexus between the original and TT. So, the translator's manner, and what he has done and what he is trying to do will, of course, show up in the translation process. Leppihalme (1997, p.18) described the role of the translator, in which he should be given due significance in a problem-restricted translation study. The translator should account for how to fix each dilemma during the translating process and bridge the source and target language gap.

Accordingly, on such a mission, the translator needs distinctive and adequate qualifications to fulfil this communication act and overcome problems. Apart from being well-versed in translation procedures and problems, it is anticipated that the translator should have a structure of ethics of his own. Muhammad (2005, p.8) indicated that the translator should be well aware of specific qualifications to carry out his/her jobs vividly and as follows: A thorough grounding in the vocabulary and expressions of both the source and target languages, B. Comprehensive recognition of the grammar, semantic, rhetoric and morphology of both source and target language, C. The translator should be faithful when rendering the ST concepts, norms and ideas, and D.The translator must be patient because the translation career requires a long period of practice and training.

Meanwhile, these proficiencies and merits are not all mandatory, signifying that the translator is the one who should have comprehensive knowledge of everything and who can accurately translate any text without any help. Moreover, the translator has to have a comprehensive understanding of both languages in question. These language potentialities qualify him/her to submit a more accurate and idiomatic translation, and thus the translation obtains a spectacular flavour.

An extensive overview of the role of the translator and the translation purpose is given by Dejica (2010, p. 139), who concludes that "the role of the translator changes depending on the purpose of the translation, and that there are as many types of translation as there are texts. Therefore, for different text types, it would seem but natural to have different translation methods." (Dejica, 2010, p.147).

\section{CONCLUSION}

This paper highlighted the key areas of translation in the history of the Arab world. It also included an attempt to discuss the methods and strategies that the translator used in Dar-Al-Hikma and how to work inside it alike. It indicated that translation played an essential role in the life of the Arab world and how it could help the Arab nations to be introduced to other nations. It has been mentioned that the different languages in the world are not a problem for people to communicating and understanding each other, since translation overcome it.

The role and the translator's decision were discussed. It indicated that it is necessary and substantial for the translator to be aware of the language system and areas of both source and target culture. A pivotal study lying behind writing the current paper is to give helpful information about the Arab history of translation. Accordingly, the importance of translating for conveying the knowledge and sciences into Arabic had increased, especially after western technology and scientific advances. On the other hand, Arab translators realised substantial shortages of translations into and out of Arabic in all domains of life and science. In sum, the variety of the Arab world's translation notions is not specific merit of this "geo-linguistic" region and custom. However, it displays the profound impacts of their transformations and the consciousness of their stakes over the very constitution of the Arab ethos and its future promises.

\section{REFERENCES}

[1] Al-Draweish, H. (1977).Al-Trajmanwa l-TaariibIndaAbu al-Rayhan Al-Bairuni.(Translation and Arabicising in the works of Al-Bairuni). Dar Ar-Rashid Lin-nashr, Baghdad.

[2] Assamara, I. (1982). The era of translation and publishing. (AsrAl-Tarjamawa Al-Nashir). Dar al Jthizlin for Publication, Baghdad.

[3] Aziz, Y. \&Lataiwish, M. (2000). Principles of Translation. Benghazi: DarAl-Kutub Al-Wataneyyah.

[4] Badawi,A. (1968). Les exigences de la traductionselon AlJahizu. In: La Transmission de la philosophieGrecque au monde Arabe. pp:21-25, Paris.

[5] Baker, M. (1992). In Other Words: A Coursebook on Translation, Routledge. London and New York: Routledge.

[6] Daniel, D. (2010).Thematic Management and Information Distribution in Translation. Timisoara: EdituraPolitehnica. 
[7] Fasold, W. \& Connor-Linton, J. (2006).An Introduction to Language andLinguistics. Cambridge: Cambridge University Press.

[8] Hatim, B. \& Munday, J. (2004). Translation: An Advanced ResourceBook. New York: Routledge.

[9] Joel, R. (1980).L'Encyclopedie de la traduction.O.P.U. Alger.

[10] Kharma, N. N. (1983). Designing a Postgraduate Course in Translation and Interpretation. W. Wiss/ G. Thome eds. 1983, pp. 221-229.

[11] Leppihalme, R. (1997). Culture Bumps: An Empirical Approach to the Translation of Allusions. Clevedon, UK: Multilingual Matters Ltd.London: Routledge.Longman.

[12] Mark, S.\& Moira, C. (1997).Dictionary of TranslationStudies, St Jerome Publishing, Manchester.

[13] Mansoor, K. (2020). The Importance of Language in the World of Translation, College of Basic Education- AlMustanssiriyahUniversity,2020 September. P: ISSN18157467. EISSN: 2706-8536.

[14] Mansoor, K. (2018). Translation Across the Difficulties of Equivalence Concept. Scientific Bulletin of the Politehnica University of Timişoara Transactions on Modern LanguagesVol. 17, Issue 1 / 2018.

[15] Mansoor, K. (2017). The concept of metaphor in the English-Arabic translation, in Dejica, D. and M. Cernicova (eds.) Professional Communication and Translation Studies, 9/2017, Timisoara: EdituraPolitehnica.

[16] Mansoor, K. (2017). The investigating semantic and syntactic equivalence in the translation process. Politechnical University Pressof Timisoara, 2017.ISBN978-606-35-0176-0.

[17] Muhammad, N. (2021).The Foundations of Translation from English into Arabic and Vice Versa.(M. Khalid, Trans.). 5th Edition, Added and Revised, Ibn Sina Library, Cairo. (2005)

[18] Remke, K. (1976).Early Arabic Translators: Their Methods and Problems. Babel 1/76 vo122 pp:16-19.

[19] Safa, K. (1982). Fannu-ttarjama (The Art of Translation). Dar Ar-Rashid Lin-nashr, Baghdad.

[20] Salah, G. (1979). How Arabic Became the International Language. The UNESCO Courier Dec.1979 p:52. 